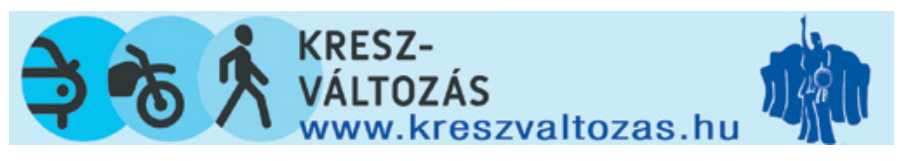

\title{
Közúti baleseti veszteségek aktualizálása
}

\author{
A közlekedésbiztonság fontos eleme a veszteségértékek teljes körü \\ feltárása és használata. Az elvégzett kutatások eredményeként a \\ teljeskörüség irányába tett jelentős lépéseket mutatják be és tesznek
} javaslatot a gyakorlati alkalmazásra.

DOI 10.24228/KTSZ.2020.4.4

\section{Prof. Dr. Holló Péter - Dr. Sipos Tibor \\ kutató professzor - vezetô kutató \\ Közlekedéstudományi Intézet Nonprofit Kft. \\ Közlekedésbiztonsági Kutatóközpont - Mobilitási Kutatóközpont \\ e-mail: hollo.peter@kti.hu, sipos.tibor@kti.hu}

\section{BEVEZETÉS}

Az írás a nemzetgazdasági közúti baleseti veszteségekkel kapcsolatos néhány elméleti és módszertani megfontolás után a SafetyCube projekt nyomán áttekintést ad arról, hogyan alakult az elmúlt években a különböző kimenetelü sérülések fajlagos (egy före jutó) nemzetgazdasági baleseti vesztesége az EU tagállamaiban. A szerzők szerint a halálos áldozatokra és a súlyos sérültekre vonatkozó hazai értékek „eurokonformnak” mondhatók, azaz nagyságrendjüket tekintve összemérhetők más tagállamok értékeivel. A könnyủ sérültek értéke azonban túlságosan alacsony volt. Ennek okait mérlegelve arra jutottak, hogy külön számítási módszer (modell) megalkotása szükséges. A cikk nem csak a modellt ismerteti, hanem az utóbbi időszak éveire, 2018-ig, megadja valamennyi kimeneteli osztályra jutó veszteségértéket.

A diagram jól szemlélteti ezek meredeken növekvő irányzatát. A szerzők hangsúlyozzák, hogy ezek az értékek egyedül a közúti biztonsági intézkedések költség-haszon elemzése során használhatók, ott viszont nagyon szükségesnek tartják az aktualizált értékek alkalmazását.

\section{BALESETI SÉRÜLTEKKEL KAPCSOLATOS VESZTESÉGEK}

A cikk elején hangsúlyoznunk kell néhány dolgot.

Elöször is, olyan, hogy „az emberélet ára” nem létezik. A kutatás során azt próbáljuk - a témával foglalkozó többi kutatóval összhangban kimutatni, hogy egy baleseti halál mekkora veszteséget jelent a társadalom, a nemzetgazdaság számára.

Az emberélet egyszeri és megismételhetetlen, s mint ilyen, fogalmilag eleve különbözik a pénztől.

A veszteségek meghatározására használt módszertan jelentős változásokon ment át, és az utóbbi évtizedekben maga a szemlélet is változott. Így pl. kezdetben nem is próbálkoztak a kutatók a veszteségek emberi oldalának (fájdalom, gyász, stb.) meghatározásával, ma már ezeket is figyelembe veszik.

Annak hangsúlyozására, hogy statisztikai adatokról beszélünk, a szakma is az SVOL rövidítést használja, ami az élet statisztikai értékét jelenti (Statistical Value Of Life). 


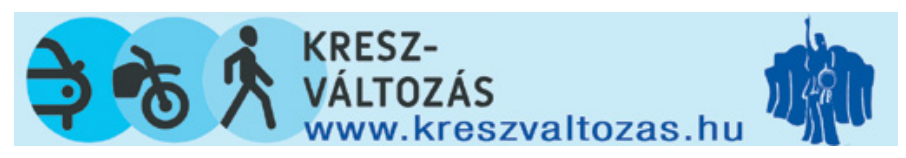

Fontos azt is hangsúlyozni, hogy a szakma (a közlekedésbiztonsági tevékenység) számára ezt nyíltan ki kell mondani - a minél nagyobb fajlagos (egy főre jutó) értékek hasznosak, mert ezek növelik igazán a szakterület súlyát, jelentőségét. (Ami nem jelenti azt, hogy az országos veszteség értéke ne lehetne alacsony.) A fajlagos értékek nagysága jól jelzi, mennyire fontos az adott ország számára a közúti biztonság.

El kell oszlatnunk azonban azt a félreértést is, hogy létezik „pontos baleseti veszteség”. Ilyen nincs. Becslésekről, közelítésekről beszélünk.

Megítélésünk szerint a baleseti veszteségek egyedüli felhasználási területe a közlekedésbiztonsági intézkedések költség-haszon elemzése. Nem szabad összekeverni ezeket a tudományos módszerekkel meghatározott értékeket semmilyen biztosítási vagy bírósági gyakorlatban elöforduló számokkal.

Annak ellenére, hogy több mint 20 éve került kifejlesztésre, mai napig a COST 313 [1] irányelv tekinthető a legátfogóbb módszertannak a közúti balesetek veszteségeinek becslésére. Ezért ezt az irányelvet fogadták el a szakértök a legfontosabb módszertani alapnak a SafetyCube [7] c. kutatási projekt keretében is, annak ellenére, hogy időközben számos új megközelítést is alkalmaztak. A 2017. évi SafetyCube projekt keretében a közúti baleseti veszteségeket társadalmi-gazdasági veszteségként értelmezték, és az alábbi fö tényezőket vették figyelembe:

- orvosi költségek (kórházbaszállítás, kórházi kezelés költsége),

- termeléskieséssel kapcsolatos veszteség,

- emberi veszteségek,

- anyagi károkkal (föleg gépjármüvekkel) kapcsolatos költségek,

- adminisztratív költségek (rendőrség, tűzoltók, biztosító társaságok),

- egyéb költségek (temetési költségek, forgalmi torlódásból adódó veszteségek, stb.).

Úgy gondoljuk, magyarázatra szorul, miért részesítettük előnyben az egyszerüsített
McMahon-Dahdah módszert a fentiekben részletezett veszteségtényezők tételes meghatározásával szemben. Utoljára a KTI-ben a 2010-es években készült a TÁRKI bevonásával, részletes, kérdezőbiztosokkal végzett reprezentatív felmérés, amely során 1000 embert kérdeztek meg a fizetési hajlandóság (Willingness To Pay: WTP) módszerével, de a termelési kapacitás csökkenését is számszerüsítették a human capital módszerrel. $\mathrm{Az}$ eredményekről beszámoló cikkben [4] a szerzők elsőként hazánkban kipróbálták a McMahon-Dahdah egyszerüsített eljárást, és többek között arra a megállapításra jutottak, hogy a kapott eredmény nagyságrendileg alig tér el a sok éven át tartó és rendkívül drága részletes felmérés eredményétől. Az egyszerüsített módszer lényege, hogy azon országok veszteségértékeire, ahol a megfelelő módszertan használatával volt elegendő tudás és anyagi forrás a részletes felmérésre, regressziós görbét illesztettek, így olyan egyszerü, ám viszonylag jó becslést adó módszert kaptak, amit ma már több ország használ. Alkalmazásához csupán az egy före jutó GDP ismerete szükséges, abból már egyszerü szorzókkal becsülhető a halálos áldozatok és súlyos sérültek fajlagos veszteségértéke nemzetközi dollárban ${ }^{1}$. Úgy gondoljuk, hogy a drága és hatalmas munkaráfordítást, megbízható alvállalkozót igénylö, hosszan tartó folyamat helyett érdemesebb az egyszerü, közelítő módszert használni. Kétségtelen hibája, hogy a könynyü sérültekre nem ad becslést. E mögött valószínüleg az a meggondolás húzódhat, hogy az ilyen sérültek vesztesége elhanyagolható a súlyos és halálos sérültek mellett. Az a tény, hogy a MacMahon-Dahdah módszer nem ad becslést a könnyü sérültekre, azt a téves benyomást kelti, mintha ezek is csak „pléhkárok” (csak anyagi káros balesetek) lennének. Pedig tudjuk, hogy ezek veszteségértéke valóban viszonylag nem túl magas, azonban az ilyen balesetekből van a legtöbb. Amint a

\footnotetext{
1 A nemzetközi dollár egy elvi pénzmennyiség, melynek vásárlóereje pontosan ugyanannyi, mint adott időben az Amerikai Egyesült Államokbéli dolláré, tehát tulajdonképpen amerikai dollár vásárlóerö-paritáson átszámítva.

Forrás:

https://hu.wikipedia.org/wiki/Nemzetk\%C3\%B6zi_doll\%C3\%Alr
} 


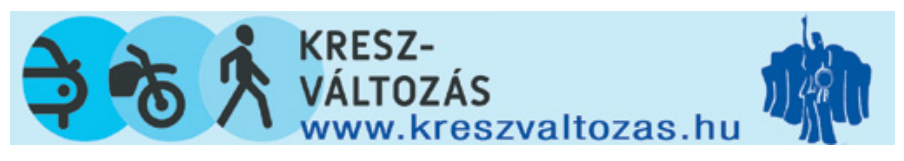

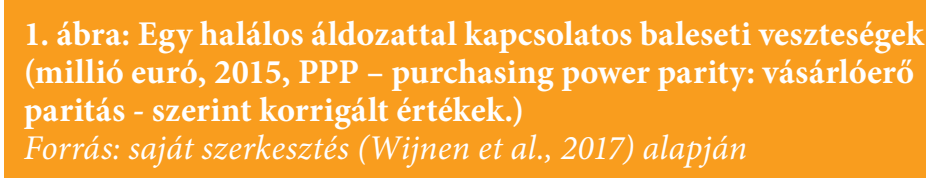

Ausztria

Franciaország

Izland

Észtország

Norvégia

Hollandia

Finnország

Horvátország

Görögország

Svédország

Magyarország

Szlovénia

Egyesült Királyság

Belgium

Dánia

Írország

Svájc

Olaszország

Málta

Spanyolország

Bulgária

Cseh Köztársaság

Németország

Lettország

Ciprus

Litvánia

Portugália

Szlovákia
0

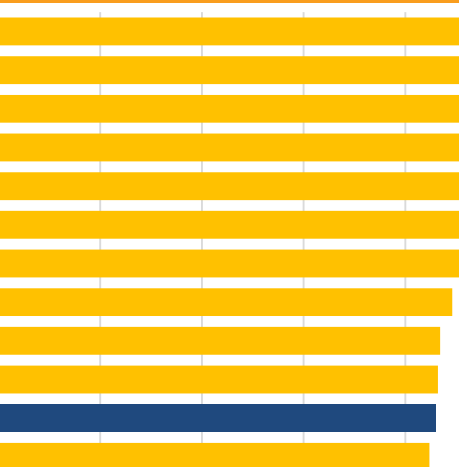

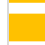
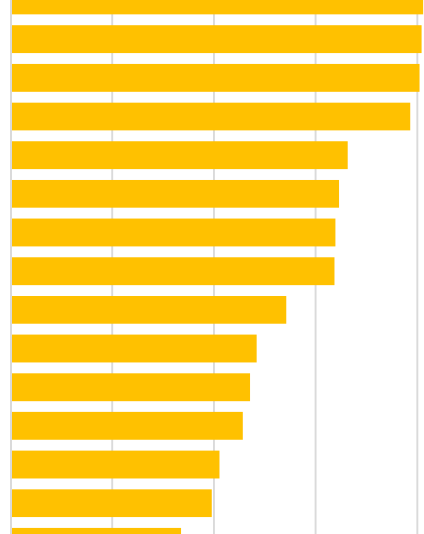

0,5

0,5

\subsection{A halálos sérül- tekkel kapcsolatos veszteségek}

A felmérés szerint egy halálos áldozattal kapcsolatos veszteségérték 0,7 millió eurótól (Szlovákia) 3,0 millió euróig terjed (Ausztria). Általánosságban megállapítható, hogy a halálos sérüléssel kapcsolatos veszteségek nagyobbak az észak- és nyugat-európai tagországokban, mint a délés kelet-európaiakban (1. ábra).

$\mathrm{Az}$ eltéréseket három tényezővel magyarázzák:

- eltérés a halálos sérült definíciójában;

- eltérés a figyelembe vett veszteségtényezőkben;

- módszertani különbségek.

\subsection{A súlyos sérültek- kel kapcsolatos veszteségek}

cikk további részéből kiderül, a módszer ezen hiányosságát külön modell megalkotásával (Dr. Sipos Tibor) orvosoltuk.

\section{BALESETI SÉRÜLTEKKEL KAPCSOLATOS VESZTESÉGEK AZ EU TAGÁLLAMAIBAN}

A SafetyCube projekt keretében a szakértők felmérték az EU tagállamaiban meghatározott veszteségértékeket. Valamennyi tagállam - Románia kivételével - szolgáltatott információt. Minden értéket euróban adtak meg, 2015-ös árszinten, figyelembe véve a relatív kereseti eltéréseket.
A súlyos sérült személy veszteségértéke a halálos sérült veszteségértékének 2,5-34\%-a. Noha ezek az értékek meglehetősen nagy szórást mutatnak, az országok háromnegyedénél a halálos áldozat veszteségértékének 10 és $20 \%$-a közé esik a súlyos sérültek vesztesége. (Mivel a hazai érték is alig haladja meg a 20\%ot, azt állapíthatjuk meg, hogy a magyar érték egyáltalán nem kirívó.) A tényleges, pénzben kifejezett értékek nagyon nagy különbségeket mutatnak. A súlyos sérültek vesztesége Lettországban a legkisebb (28 000 euró) és Észtországban a legnagyobb (959 000 euró). Lengyelországot azért hagyták ki az elemzésből, mert ott a súlyos sérültekre meghatározott 


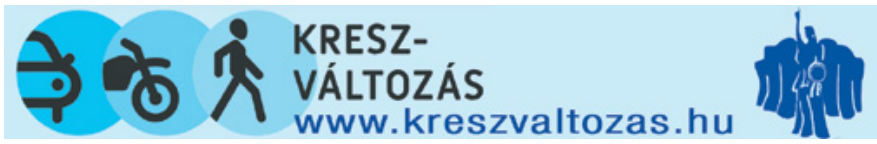
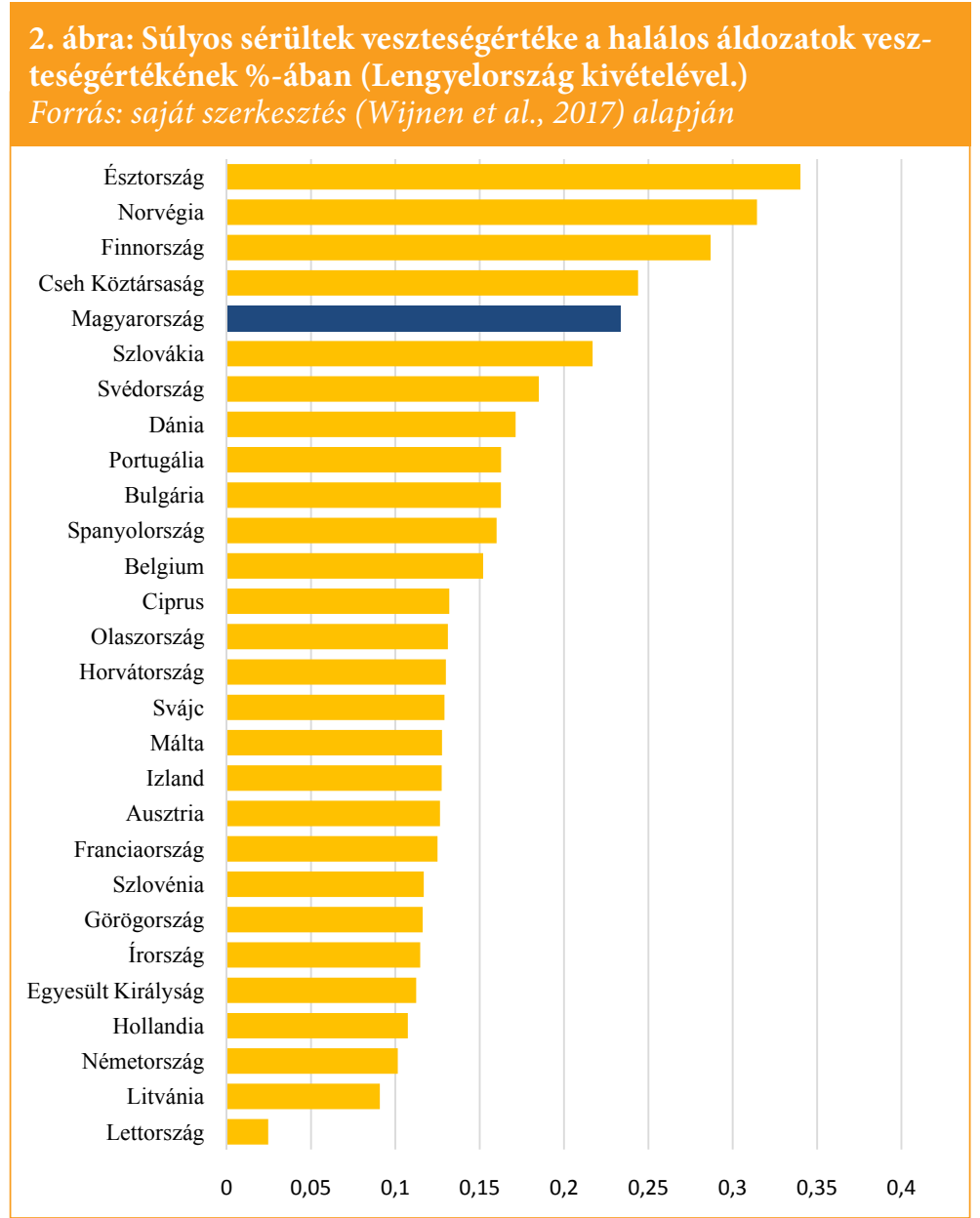

alacsony. Ennek az az oka, hogy az általunk használt McMahonDahdah módszer nem ad becslést ezekre, illetve a régi érték aktualizálása elmaradt. Ezért a téma keretében olyan modell került kidolgozásra, amely lehetővé teszi a könnyü sérültek fajlagos (KSV) és eurokonformnak mondható veszteségének meghatározását [6].

A modell alapjául a nemzetközi könnyü sérülés statisztikai veszteségértékére vonatkozó értékek szolgáltak, melyek a SafetyCube 2017. projektből származnak [7].

A nemzetközi adatokra GLM (Generalized Linear Model) típusú regressziót illesztettünk. A számításokhoz az $\mathrm{R}$ stúdió 3.4 .0 statisztikai szoftvert alkalmaztuk [2], [5]. Az

veszteségérték - egyedülálló és szakmailag elfogadhatatlan módon - nagyobb volt a halálos áldozatokra meghatározott értéknél (2. ábra).

\subsection{A könnyü sérültekkel kapcsolatos vesz- teségek}

A könnyű sérültek veszteségértékeit szintén a halálos áldozatokra meghatározott érték százalékában hasonlították össze (3. ábra).

\section{A HAZAI ÉRTÉKEK AKTUALIZÁLÁSA}

Az összehasonlításokból is látható, hogy míg a halálos és súlyos sérültekre vonatkozó veszteségérték eurokonformnak mondható, addig a könnyü sérültek becsült vesztesége eurokonform könnyű sérülés statisztikai veszteségértékének meghatározására így az alább formula használható:

$K S V=e^{10,447-3,571 \cdot 10^{-4}} \cdot\left[\frac{\text { kōnnyû̃ sérūléses balesetek száma }}{\text { halálos kimenetelú balesetek száma }}\right.$. $\ln$ (Egy fóre jutó GDP[PPS]

A halálos és súlyos sérülés statisztikai veszteségértékeinek becsült értékei a McMahonDahdah [3] módszertan alapján, a könnyü sérülés statisztikai veszteségének becsült értékei pedig a KTI (Dr. Sipos Tibor) által kidolgozott módszertan alapján kerültek meghatározásra.

A 4. ábrából világosan látható, hogy évrőlévre növekednek a fajlagos veszteségértékek. 


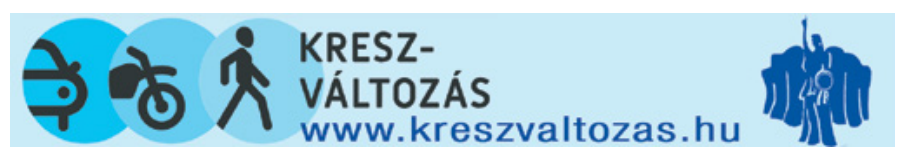

\section{3. ábra: Könnyü sérültek veszteségértéke a halálos áldozatok veszteségértékének \%-ában. \\ Forrás: saját szerkesztés (Wijnen et al., 2017) alapján}

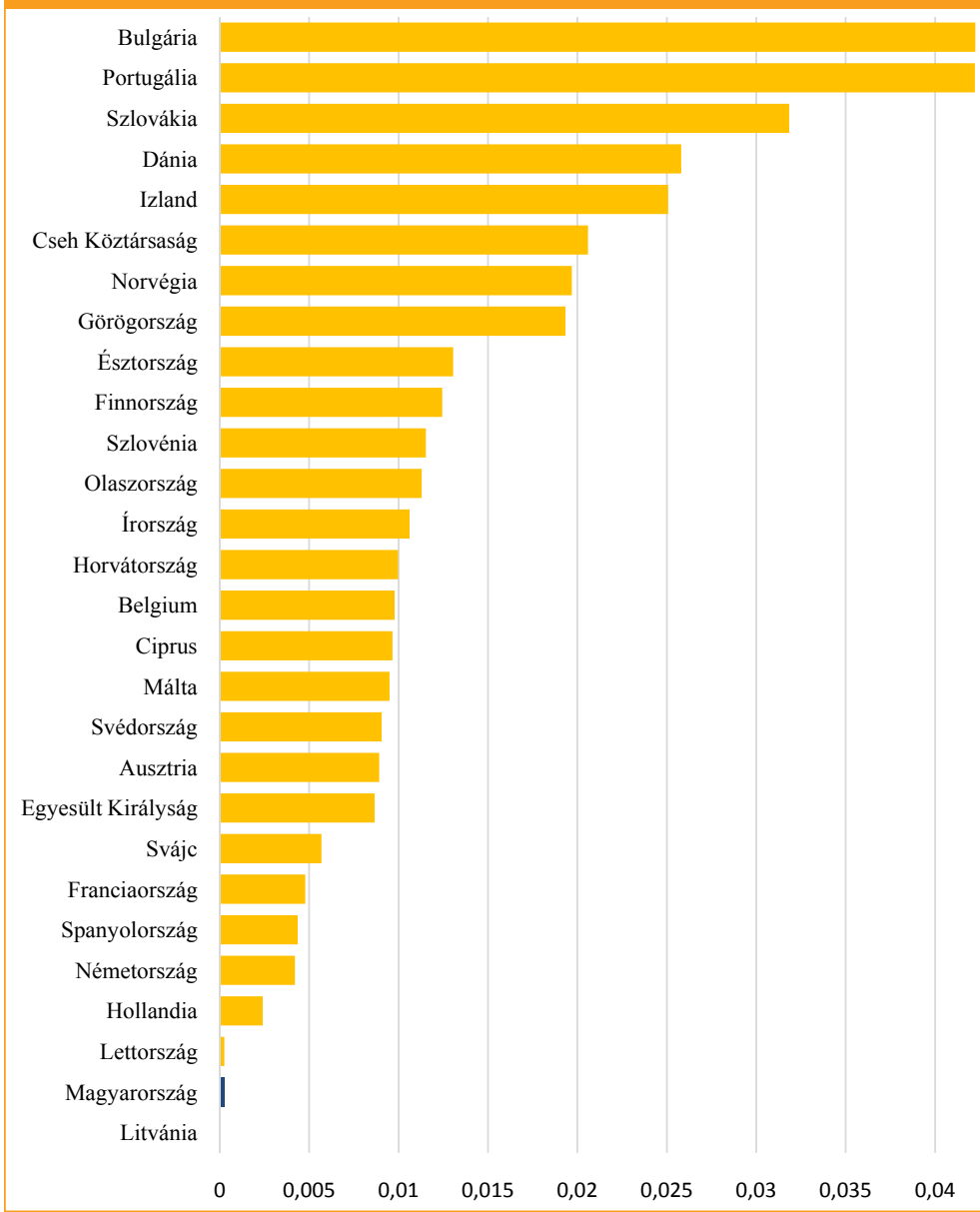

A gyors növekedés föként a halálos és könynyű sérültekre jellemző. Míg a halálos áldozat fajlagos vesztségértéke 2010-ben a 200 millió Ft/áldozat értéket sem érte el, addig 2018-ban már a 300 millió Ft/áldozat értéket is meghaladta.

Mint a bevezetőben említettük, a fenti értékek egyedüli felhasználási területe a közúti közlekedésbiztonsági intézkedések költséghaszon elemzése. Mivel a fajlagos veszteségértékek gyakorlatilag évröl-évre növekednek, súlyos hibát okozhat az elemzésben, ha elavult értékeket használunk. Információink szerint a szakmai gyakorlatban nem alkalmazzák az aktualizált értékeket, nem is hallottunk, olvastunk ilyenekről a hazai szakirodalomban. Véleményünk szerint a leírt módszerekkel meghatározott

\section{1. táblázat: A halálos, súlyos és könnyut sérülés statisztikai veszteségértékei}

\begin{tabular}{|l|c|c|c|}
\hline & $\begin{array}{c}\text { Halálos áldozat statisztikai veszteség- } \\
\text { értéke [Ft/áldozat] (McMahon-Dahdah } \\
\text { módszertan alapján) }\end{array}$ & $\begin{array}{c}\text { Súlyos sérülés statisztikai veszteség- } \\
\text { értéke [Ft/sérült] (McMahon-Dahdah } \\
\text { módszertan alapján) }\end{array}$ & $\begin{array}{c}\text { Könnyủ sérülés statisztikai veszteség- } \\
\text { értéke [Ft/sérült] (KTI modell alapján) }\end{array}$ \\
\hline 2010 & 190881686 & 46356981 & 5190938 \\
\hline 2011 & 199158583 & 48367084 & 5100402 \\
\hline 2012 & 203556594 & 49435173 & 5147777 \\
\hline 2013 & 214323796 & 52050065 & 5256145 \\
\hline 2014 & 231956822 & 56332371 & 5449702 \\
\hline 2015 & 247379595 & 60077902 & 5468162 \\
\hline 2016 & 256035983 & 62180167 & 5692145 \\
\hline 2017 & 277735484 & 67450046 & 5960853 \\
\hline 2018 & 305700898 & 74241647 & 6118179 \\
\hline
\end{tabular}



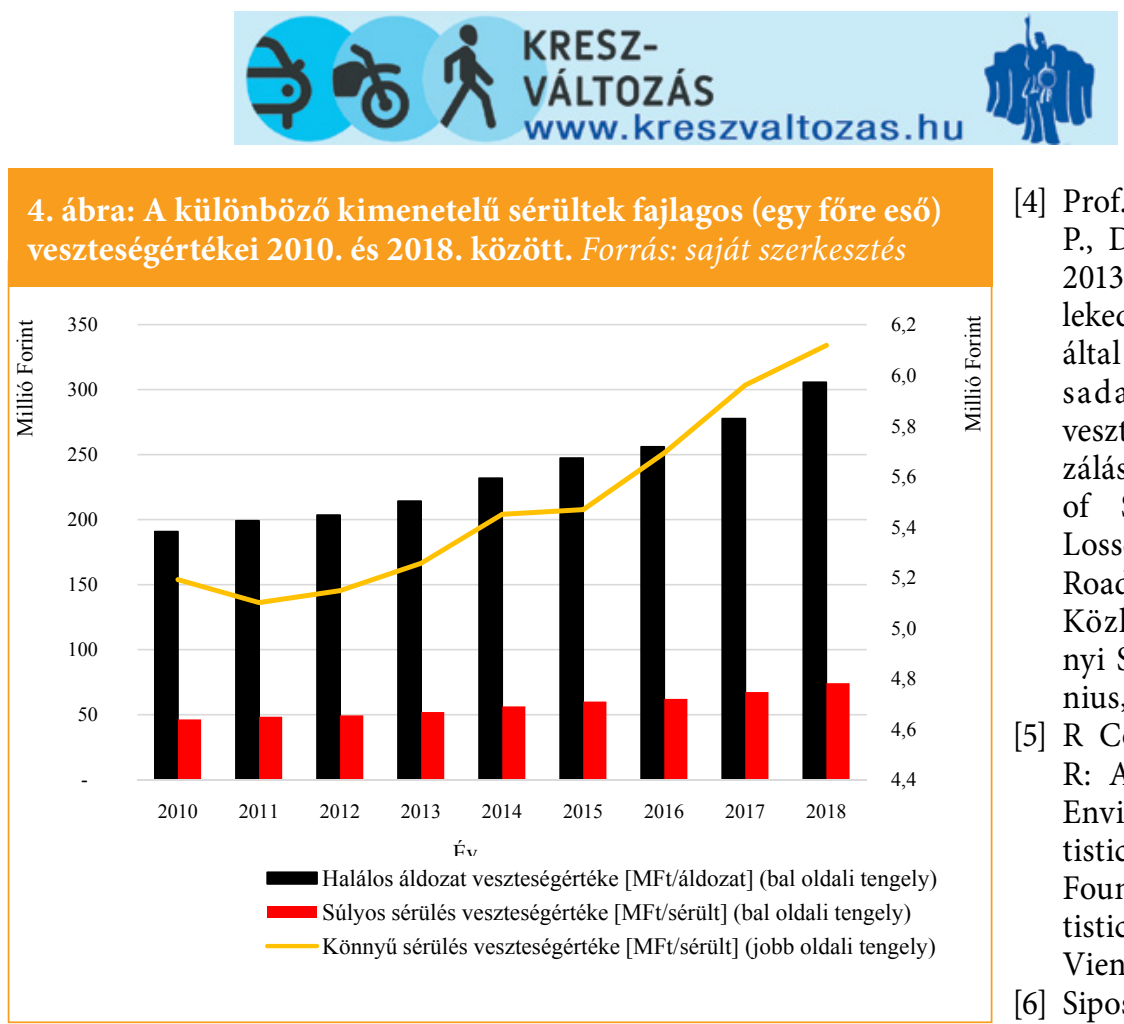

[4] Prof. DSc. Holló, P., Dr. Hermann, I., 2013. A közúti közlekedési balesetek által okozott társadalmi-gazdasági veszteségek aktualizálása (Actualization of Social-Economic Losses Caused by Road Accidents). Közlekedéstudományi Szemle, 2013. június, 22-27.

[5] R Core Team, 2019. $\mathrm{R}$ : A Language and Environment for Statistical Computing. R Foundation for Statistical Computing, Vienna, Austria.

[6] Sipos, T., Bokor, Z., Mészáros, F., 2012.

értékek egyrészt eurokonformnak mondhatók, másrészt évente rendelkezésre állnak. Ezek költség-haszon elemzések során történő használatát fontosnak tartjuk, hiszen csak így vezethetnek az elemzések reális eredményre. Szükségesnek ítéljük a költség-haszon elemzésre vonatkozó elöírások e tekintetben történő átdolgozását is. A KTI szakemberei ezután is meghatározzák és a szakma rendelkezésére bocsátják az éves veszteségértékeket. Javasoljuk, hogy ezeket fogadják el „hivatalos értéknek" is. Ismereteink szerint az aktuális veszteségértékek meghatározására csak a KTI-ben folytak kutatások.

\section{FELHASZNÁLT IRODALOM}

[1] Alfaro, J.-L., Chapuis, M., Fabre, F., 1994. COST 313. Socioeconomic cost of road accidents. Report EUR 15464 EN, Commission of the European Communities. Brüsszel, Belgium.

[2] Gross, J., Ligges, U., 2015. nortest: Tests for Normality.

[3] McMahon, K., Dahdah, S., 2008. The true cost of road crashes - Valuing life and the cost of a serious injury.
A közúti közlekedés társadalmi költségeinek meghatározása. Közlekedéstudományi Szemle 62, 31-35.

[7] Wijnen, W., Weimars, W., Vanden Berghe, W., Schoeters, A., Bauer, R., Carnis, L., Elvik, R., Theofilatos, A., Filtness, A., Reed, S., Perez, C., Martensen, H., 2017. Crash cost estimates for European countries, Deliverable 3.2 of the $\mathrm{H} 2020$ project SafetyCube. Belgium.

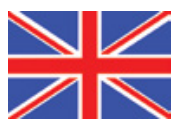

Actualisation of road accident losses

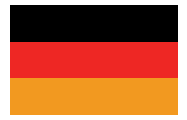

\section{Aktualisierung von Verkehrsunfallverlusten}

